Researches

\title{
Preparation of De-emulsifier of Gemini Surfactant \& it's Application in Oil Industry
}

\author{
Prof. Dr. Georgius A. Adem. University of Ciduny .Australia \\ Zaydoon K. Kreamid / PRDC
}

\section{Abstract:}

A Gemini surfactants (GS) which are bis quaternary ammonium salt. It is prepared from tetramethyl ethylene diamine (TMEDA) with cetyl bromide, while an ordinary surfactant (OS), which is quaternary ammonium salt, is prepared from trimethyl amine (TMA) and cetyl bromide. They were identified by elemental analysis and IR spectroscopy.

Comparing the GS,OS and the commercial surfactants, the Gemini surfactant shows an interesting properties and have a variety of uses, such as a De-emulsifier.

Adopting the composition ratios found in the study of reverse chemistry of commercial Deemulsifier, Rp 6000, which is usually use in the south and north oil companies in Iraq. The prepares active gradients were characterized by various techniques, IR spectroscopy, elemental analysis, melting point, solubility, flash point and functional group analysis.

The efficiency of the prepared De-emulsifier was examined by standard methods and compared with the efficiency of commercial Rp 6000 based on the same wet crude oil sources.

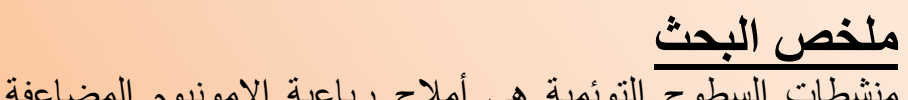
منشطات السطوح التوئمية هي أملاح رباعية الامونيوم المضاعفة الإية

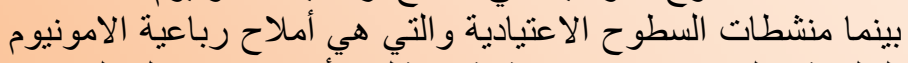

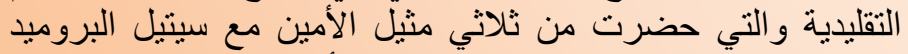

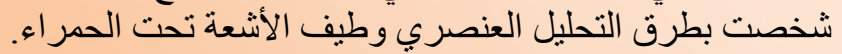

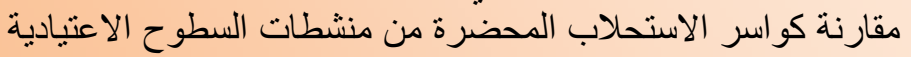

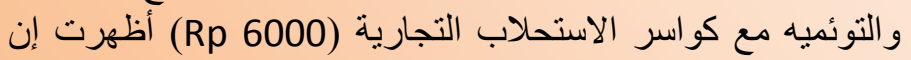

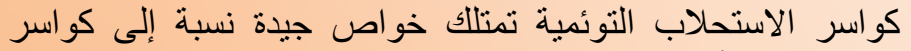

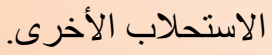

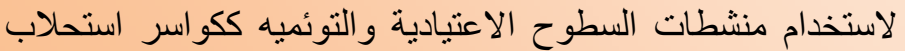

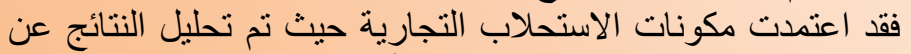

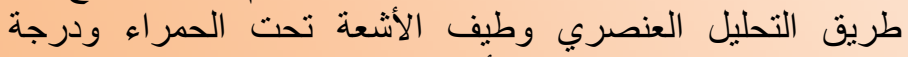

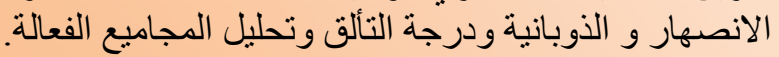

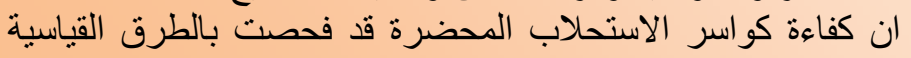

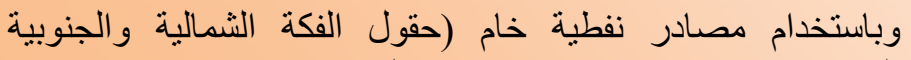
العر اقية) مع كفاءة كو اسر الاستحلاب التجارية (Rp 6000).

\section{1-Introduction:}

Emulsions are unstable thermodynamic systems which contain two immiscible liquid phases. The emulsion causes many problems such as corrosion, or effect the quality and properties of oil. One of the methods of treatment of this problem is by using De-emulsifier (tensider or emulsion breaker). ${ }^{(1)}$

These systems can be dissociate in the presence of a kind of surfactants known as emulsifying agents. These agents consist of two groups, polar (hydrophilic) like aqueous phase and non polar group (hydrophobic) like an oil. ${ }^{(2)}$

Surfactants were known for a long time, and known for the ancient Egyptians and Babylonians, and they were made of animal fats and plants oil. They were used for detergents, drugs, dyes and many other industries such as emulsifiers and De-emulsifiers. ${ }^{(3)}$

The De-emulsifiers reduce the surface tension for liquids and then dissociate the large oil blocks. They increase the interfacial action. ${ }^{(4)}$ This activity depends on the nature of surface active material, the molecular weight and the length of the molecular chain. 
In this work we used a surfactant which can be used in an oil industry as an important economic field, As it is well known, there are two kinds of emulsions in an oil industry, water/oil (W/O), and oil/water $(\mathrm{O} / \mathrm{W}){ }^{(5)}$ The difference between them is the nature of the dispersed and continuous phases. Each one has its own method.

We deal with $(\mathrm{W} / \mathrm{O})$ emulsion to treat the crude oil, which is as a result of the injection of water into the oil wells. To get better efficiency of surfactant, we used a Gemini surfactant $(G S)^{(6)}$, which have many hydrophilic groups linked together by spacer. ${ }^{(7)}$

\section{2- Experimental Work:} Preparation of the Compounds:

\section{2-1 Preparation of cetyl bromide} $\left(\mathrm{CH}_{3}\left(\mathrm{CH}_{2}\right)_{15} \mathrm{Br}\right)^{(8)}$ :

A mixture of $10 \mathrm{~g}$ (0.043 mole) of cetyl alcohol and $33 \mathrm{ml}(0.215$ mole) of $48 \% \mathrm{HBr}$ (1:5 mole ratio) was refluxed for 4 hours. The reaction mixture then cooled, and the uncreated cetyl alcohol was extracted with absolute methanol (3 times).

The liquid product then dried with anhydrous $\mathrm{MgSO}_{4}$ The cetyl bromide then distilled. The yield is $75 \%$ (9.5 g). bp: $122-124{ }^{\circ} \mathrm{C}$, $\mathrm{mp}: 16.18 \circ \mathrm{C}^{(9)}$
2-2 Preparation of GS (quaternary ammonium salt):

Tertiary ammonium salt was prepared in two necked round bottomed flask fitted with separating funnel and condenser. A solution of $6.3 \mathrm{ml}$ (0.01 mole) of tetramethyl ethylene diamine and $30 \mathrm{ml}$ of dry ethanol as a solvent was placed in the flask. The solution then heated to $50{ }^{\circ} \mathrm{C}$ and then $60.2 \mathrm{ml}$ (0.02 mole) of cetyl bromide was added drop wise by the separating funnel for 60 minutes at $50 \circ$ C. After the addition was completed,

The temperature raised to $80 \circ \mathrm{C}$ and the reaction was continued for 24 hours. The solvent then evaporated by rotary evaporator.

The product is a white solid material which was dried and then re-crystallized with a mixture of hexane and ethanol $(1: 1) .{ }^{(9)}$ The product is soluble in water, xylene and toluene. The yield is $67.5 \%(50.1 \mathrm{~g})$.

\section{2-3 Preparation of ordinary surfactant (OS):}

In three naked rounded bottomed flask fitted with mechanical stirrer, separating funnel and condenser $11.82 \mathrm{~g}$ (0.02 mole) of trimthy amine (TMA) was placed followed by the addition of a solution of 30.5 
g ( 0.01 mole) of cetyl bromide in $50 \mathrm{ml}$ of xylene by the separating funnel dropwise with stirring for 9 hours at $105{ }^{\circ} \mathrm{C}$.

The heating was in an oil bath.
The white solid product then re-crystallized from ethey acetate. Decomposing temperature is $251{ }^{\circ} \mathrm{C}$, The yield is $53.6 \%$ (19.5 g).

\section{Identification of the Compounds and Discussion:}

\section{3-1 CHN Analysis}

The suggested reaction for the preparation of $\mathrm{Gs}$ is:

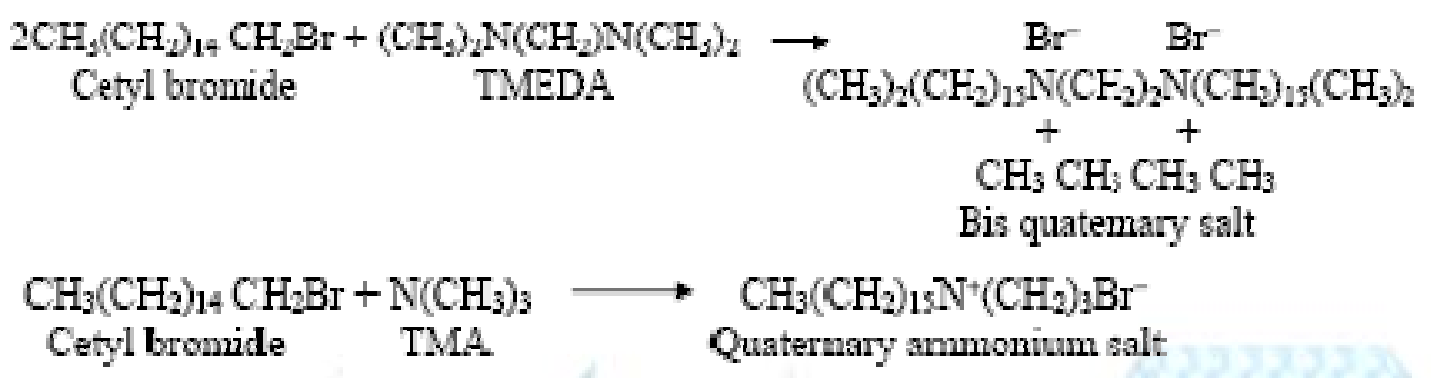

The prepared compounds were characterized by CHN analysis:

For GS:

Calculated: $\mathrm{C}=62.61, \mathrm{H}=11.616, \mathrm{~N}=3.844$.

Found $: \mathrm{C}=62.89, \mathrm{H}=11.316, \mathrm{~N}=3.955$.

For OS:

Calculated: $\mathrm{C}=62.78, \mathrm{H}=11.371, \mathrm{~N}=3.854$.

Found $: \mathrm{C}=63.01, \mathrm{H}=11.213, \mathrm{~N}=3.975$.

The IR spectra for GS and OS figure (1 and 2) show a similarity which is due to a similarity in general structure. The spectra shows the $\mathrm{C}-\mathrm{N}$ and $\mathrm{C}-\mathrm{H}$ stretching vibration at $1450 \mathrm{~cm}^{-1}$ and $2980 \mathrm{~cm}^{-1}$ respectively and $\mathrm{C}-\mathrm{H}$ bending at $1370 \mathrm{~cm}^{-1}$ in addition to $\mathrm{CH}_{2}$ bending vibration for the rest of aliphatic chain at $730 \mathrm{~cm}^{-1}$. The spectra where performed by Shimatzu FT-IR 8400s in the petrochemical company, Basrah, Iraq.
3-2 Reverse chemistry and analysis of commercial surfactant with trade mark Rp6000

Due to the importance of the Rp6000 as W/O De-emulsifier, it was analyzed using reverse chemistry method. $100 \mathrm{ml}$ of $\mathrm{Rp}$ 6000 where distillated at $163{ }^{\circ} \mathrm{C}$, giving $80 \mathrm{ml}$ solvent and $20 \mathrm{~g}$ of solid residue.

Comparing the boiling point of the solvent with the literatures shows that it is similar to Mesitylene (bp:163 - 164). The analysis results were shown in tables (1) and (2). 
Table (1) The Results of the Reverse Chemistry of Rp 6000

\begin{tabular}{|c|c|c|c|c|c|}
\hline Compound & $\begin{array}{c}\text { Refractive } \\
\text { Index }\end{array}$ & $\begin{array}{c}\text { Aromaticity } \\
\text { Test }\end{array}$ & $\begin{array}{c}\text { Sulpher test } \\
\text { (qualitative) }\end{array}$ & $\begin{array}{c}\text { Density } \\
\mathrm{g} / \mathrm{ml}\end{array}$ & $\begin{array}{c}\text { Solid Liquid } \\
\mathrm{g} / \mathrm{ml}\end{array}$ \\
\hline $\begin{array}{c}1,3,5 \text { tri methyl } \\
\text { benzene (Mesitylen) } \\
\text { Experimental }\end{array}$ & 1.49846 & + & + & 0.8638 & $20 / 80$ \\
\hline $\begin{array}{c}\text { literature } \\
\text { itrature }\end{array}$ & 1.4990 & + & + & 0.8640 & $20 / 80$ \\
\hline
\end{tabular}

Table (2) The Elemental Analysis For The Solid Residue For Rp 6000

\section{Distillation}

The predicted compound $\mathrm{RN} \mathrm{HSO}_{3}$

Calculated

$\mathrm{Na}\left(\mathrm{C}_{17} \mathrm{H}_{36} \mathrm{NSO}_{3}{ }^{-} \mathrm{Na}^{+}\right)$Found

C
$\mathrm{H}$
$\mathrm{N}$

60.01

9.915

3.925

C

58.176

$\mathrm{H}$

$\mathrm{N}$

10.308

3.77

IR for solid residue, figure (3), C-H: stretching vibration $2980 \mathrm{~cm}^{-1}, \mathrm{C}-\mathrm{H}$ : Bending vibration $1380 \mathrm{~cm}^{-1}, \mathrm{~N}-\mathrm{H}$ : stretching vibration $3490 \mathrm{~cm}^{-1}, \mathrm{~S}=\mathrm{O}$ : stretching vibration $1250 \mathrm{~cm}^{-1}, \mathrm{~N}-\mathrm{S}$ : stretching vibration $1220 \mathrm{~cm}^{-1}$.

4- Preparation of De-emulsifiers:

4-1 Preparation of Gemini Deemulsifier (Dgm)

The Gemini De-emulsifier was prepared by mixing the same structural proportions as it was found for the commertial $\mathrm{Rp}$ $6000(20 / 80 \mathrm{~g} / \mathrm{ml})$ :

$(10 \mathrm{~g})$ of GS, $(5 \mathrm{~g})$ of Benzene sulphonic acid and $(5 \mathrm{~g})$ of oil type $(50 \mathrm{~S})^{(7)},(75 \mathrm{ml})$ of a Solvent mixing (Toluene, Xylene) 2/1 $(\mathrm{v} / \mathrm{v})\}$, and $(5 \mathrm{ml})$ of $1000 \mathrm{ppm}$ of $\mathrm{AgNO}_{3}$ Solution.

The sulphonic acid was used to increase the viscosity and to reduce the cohesion forces between the immiscible phases $\mathrm{AgNO}_{3}$ solution was used in order to increasing the efficiency of separation. ${ }^{(5)}$

\section{4-2 Preparation of} conversational De-emulsifier (Dos)

It was prepared following the same procedure for (GS) by introducing ordinary surfactant (OS) instead of the GS. ${ }^{(7)}$

4-3 The physical properties of the De-emulsifiers

Some of the physical properties of Dgs, Dos and Rp 6000 as measured experimentally are shown in table (3) bellow, The measurements were taken at $25^{\circ} \mathrm{C}$. 
Table (3) shown a similarity in them physical properties

\begin{tabular}{|c|c|c|c|c|c|}
\hline $\begin{array}{l}\text { The } \\
\text { material }\end{array}$ & $\begin{array}{l}\text { Density } \\
\mathrm{g} / \mathrm{ml}\end{array}$ & $\begin{array}{c}\text { Viscosity } \\
\text { (Contipoise) }\end{array}$ & $\begin{array}{l}\text { Refractive } \\
\text { index }\end{array}$ & PH & $\begin{array}{l}\text { Flash } \\
\text { point }{ }^{\circ} \mathrm{C}\end{array}$ \\
\hline $\operatorname{Rp} 6000$ & 0.877 & 1.4905 & 1.50117 & 5.8 & 57 \\
\hline Dom & 0.8767 & 1.4896 & 1.500087 & 5.8 & 55 \\
\hline Dos & 0.8920 & & 1.5267 & 5.8 & 61 \\
\hline $\begin{array}{l}\text { 5- Results } \\
\text { A Gem } \\
\text { interesting } \\
\text { properties } \\
\text { variety o } \\
\text { prepared } \\
\text { this pape } \\
\text { formulatio }\end{array}$ & $\begin{array}{l}\text { surfact } \\
\text { terfacial } \\
\text { ind have } \\
\text { use, u } \\
\text { mini sur } \\
\text { were } \\
\text { of c }\end{array}$ & $\begin{array}{l}\text { ts show } \\
\text { and bulk } \\
\text { a wide } \\
\text { ere the } \\
\text { ctants in } \\
\text { ed the } \\
\text { mulsifier. }\end{array}$ & \multicolumn{3}{|c|}{$\begin{array}{l}\text { standard methods and compared } \\
\text { with the efficiency of Rp } 6000 \\
\text { based on the same } \\
\text { concentration and evaluated } \\
\text { relatively with concentration } \\
\text { rang }(20-50 \mathrm{ppm}) \text { as shown in } \\
\text { tables and curves }(4,5,6)\end{array}$} \\
\hline \multicolumn{6}{|c|}{$\begin{array}{l}\text { Adopting the composition De- } \\
\text { emulsifier (Rp 6000) which was }\end{array}$} \\
\hline \multicolumn{6}{|c|}{ used in south and north oil } \\
\hline \multicolumn{6}{|c|}{ companies ((wells)). } \\
\hline \multicolumn{6}{|c|}{ The prepared active gradients } \\
\hline & & & & & \\
\hline $\begin{array}{l}\text { CHN, M.P } \\
\text { and functi }\end{array}$ & ubility, & & & & \\
\hline
\end{tabular}

The efficiency of the prepared de-emulsifier were examined by

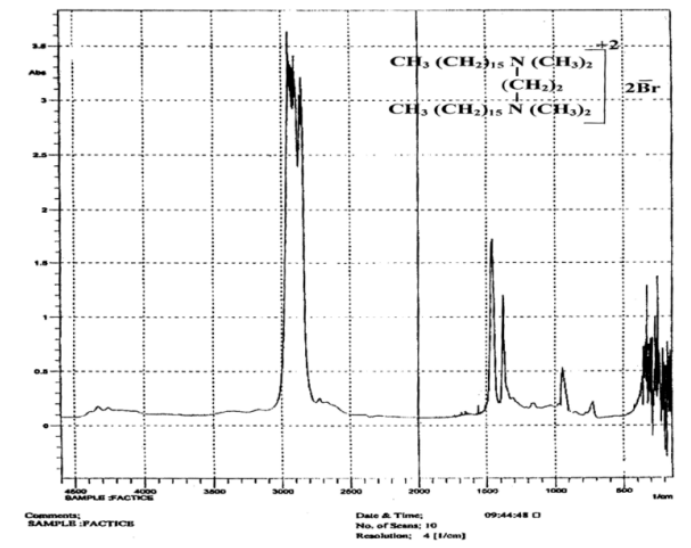

Figure (2) Shown Infrared Spect. Of (GS)Gemini Surfactant
Figure (1) Shown Infrared Spect. Of (OS) Surfactant

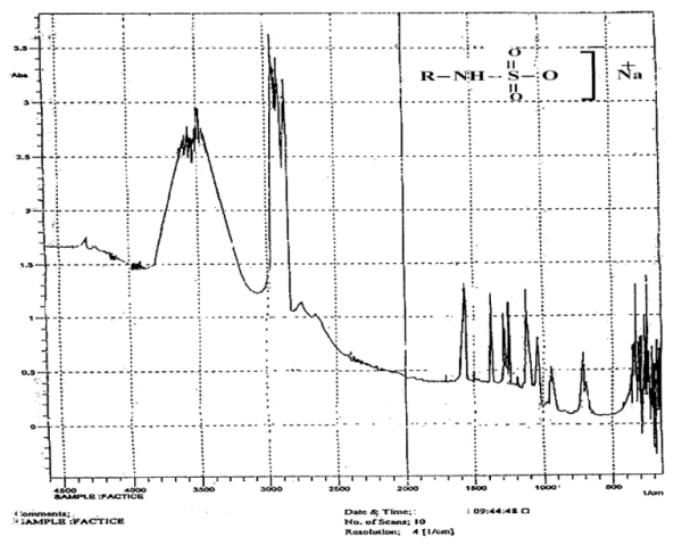

Figure (3) Shown Infrared Spect. Of Rp 6000 
Table (4) illustrated The Efficiency Value and Water Separated Ratio to time for Dgm Compared with Rp 600(50 ppm) 15\% (W/O) Emulsion

\begin{tabular}{|l|l|l|l|l|}
\hline Time (min) & 15 & 30 & 45 & 60 \\
\hline Material & \multicolumn{4}{|l|}{ Volume of $\mathrm{H}_{2} \mathrm{O}(\mathrm{ml})$} \\
\hline Dgm1 & 0.9 & 1.2 & 1.4 & 1.5 \\
\hline$\underline{\text { Rp 6000 }}$ & 1.1 & 1.3 & 1.5 & 1.5 \\
\hline Efficiency\% & 81.8 & 92.3 & 93.3 & 100 \\
\hline
\end{tabular}

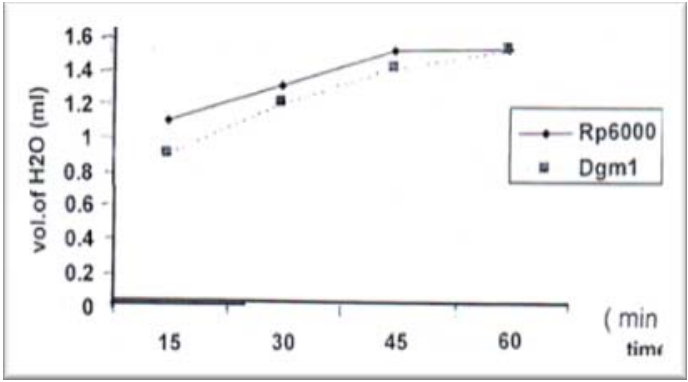

Figure (4)

Table (5) illustrated The Efficiency Value and Water Separated Ratio to time for Dgm Compared with Rp $6000(20 \mu \mathrm{g} / \mathrm{ml})$ 15\% (W/O) Emulsion

\begin{tabular}{|l|l|l|l|l|l|}
\hline Time $(\mathrm{min})$ & 15 & 30 & 45 & 60 \\
\hline Material & \multicolumn{4}{|c|}{ Volume of $\mathrm{H}_{2} \mathrm{O}(\mathrm{ml})$} \\
\hline Dgm1 & 0.8 & 0.9 & 1.1 & 1.3 \\
\hline Rp 6000 & 0.9 & 1.1 & 1.3 & 1.4 \\
\hline Efficiency\% & 88.8 & 81.8 & 84.6 & 92.6 \\
\hline
\end{tabular}

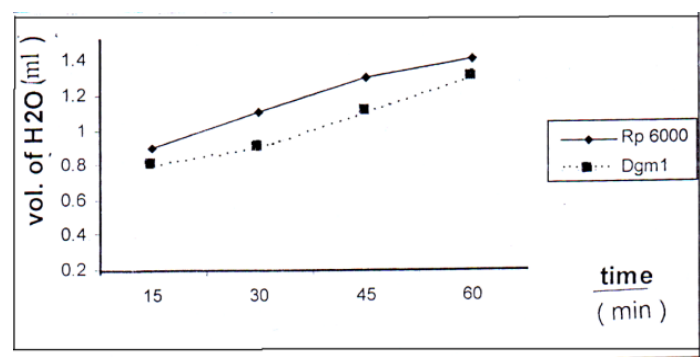

Figure (5)

Table (6) illustrated The Efficiency Value and Water Separated Ratio to time for Dom Compared with $\mathrm{Rp}$ 6000(50 $\mu \mathrm{g} / \mathrm{ml}$ ) 15\% (W/O) Emulsion

\begin{tabular}{|l|l|l|l|l|l|}
\hline Time (min) & 15 & 30 & 45 & 60 \\
\hline Material & \multicolumn{4}{|l|}{ Volume of $\mathrm{H}_{2} \mathrm{O}(\mathrm{ml})$} \\
\hline Dom & 0.9 & 1.1 & 1.3 & 1.4 \\
\hline Rp 6000 & 1.4 & 1.5 & 1.5 & 1.5 \\
\hline Efficiency\% & 64.2 & 73.3 & 86.6 & 93.3 \\
\hline
\end{tabular}

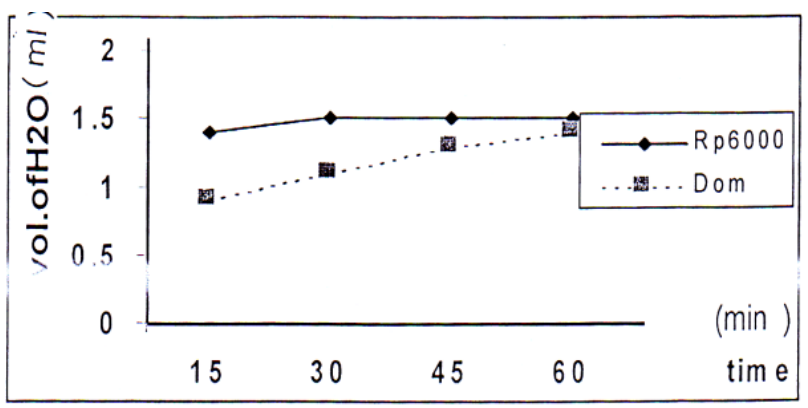

Figure (6)

\section{6- Conclusion}

The prepared surfactants were applied for types of (W/O) sample mixtures (high proportion and low proportion of water).

The first samples were taken from northern and southern Feka $\left(F_{n}, F_{s}\right)$ which are belong to meisan oil fields, which have large proportion of water. The second sample was taken from Bazirgan oil fields which have low proportions of water (25\%).

The oil of low proportion of water (second type) was separated using a high concentration of commercial deemulsifier ( $R p$ 6000) to get dry oil, which then mixed with water of a proportion of $10 \%(\mathrm{~W} / \mathrm{O})$ in a test tube with a continuous stirring for one hour. The deemulsifier concentration was in the range $20-50 \mu \mathrm{g} / \mathrm{ml}$ of Dgm, Dom and $\mathrm{Rp} 6000$ to the volume of the emulsion.

The results were with blank sample which were all left for 30 minutes in a water bath at $50{ }^{\circ} \mathrm{C}$. The temperature of $50{ }^{\circ} \mathrm{C}$ was taken as an average of the 
operating temperature range of $40-60{ }^{\circ} \mathrm{C}$ in an oil companies in Iraq. ${ }^{(9)}$

The study shows that the higher concentration for all deemulsifiers have better separation efficiency, as the temperature reduce the surface tension according to Vonetove relation. ${ }^{(10)}$

The study shows that Dgs has excellent separation efficiency and fast in compared to the three de-emulsifiers.

The $50 \mu \mathrm{g} / \mathrm{ml}$ emulsifier was applied for different crude oils from the above mentioned oil fields with different $\mathrm{W} / \mathrm{O}$ ratios $(10,15,25) \%$. The higher concentration for all deemulsifier has better effect on reducing the surface tension and causes an easier penetration to the layer surrounding the water droplets. The Dgs has an excellent efficiency for all $\mathrm{W} / \mathrm{O}$

\section{7- References}

1) S. Ross and I.D Morrision ,(1988) "colloidal system and interfaces", John wiley and sons, 132,267.

2) Alfred Martin, (1989) Physical Pharmacy, John Wiliey and Sons, London, $4^{\text {th }} \mathrm{Ed}$,

3) F.M. Manger, C.A. Littau, J.am. (2000) Chem. Soc,113, 1451.

4) D.Hummel (1968) "Identification and analysis of surface active agents" John Willy and sone, London.

5) D.J.Show (1970)"Introduction to colloid and colloid and surface ratio and for all de-emulsifier's percentages.

The study shows that Dgm has better separation efficiency in compared to Dom and nearly similar efficiency to the commercial de-emulsifier (Rp $6000)$ for all (W/O) proportion and for all periods of times.

From this study we can conclude that the most important factors effecting the de-emulsification are temperature, type of oil, the concentration of the deemulsifier and time. ${ }^{(11)}$

The prepared emulsifier, Dgm, can be used for the oil industry in Iraq, especially the technology of emulsification is restricted to the center international companies, Southern oil company concerns about 50 barrel/day of Rp 6000 .

chemistry" Bytter Worth, London, $2^{\text {nd }}$ ed, 206.

6) Y.P.Zhu, A. Masuyama, Y. Kirito, M. okahata, J. Am. (1991) Oil chem..Soc. 68, 539.

7) Q. Rist, A. Rike, Ljones and H.G.Carrosion. J. Macromolecules.6,979

8) R. S. Shelton, J. Am, (1946) Chem. Soc, 68, 1,753.

9) "Markiting specification of Iraqi petroleum products (1991) "217, Baghdad.

10) T. Leslie, (1994) Ph. D. Thesis, Emory Univ, USA.

11) Z. k. Kreamid, (2004) M. Sc. Thesis, Basrah University, Iraq. 